\title{
Determination of water retention curves for one residual soil and two distinct non-woven geotextiles
}

\author{
Raul Graça ${ }^{1}$, Maria Almeida ${ }^{1}$ and Lúcio $\operatorname{Villar}^{1}$ \\ ${ }^{1}$ Federal University of Minas Gerais, Brazil
}

\begin{abstract}
The water retention curves (WRC) presented in this study were determined for materials constituting prototypes of evapotranspirative capillary barrier coverage, which used gneissic residual soil and non-woven geotextile. The determination of the WRC was made possible by the hanging column test for the two distinct non-woven geotextiles and the hanging column and filter paper tests for the residual soil. Both tests were executed with both the drying and wetting trajectories. The curves were adjusted and the hydraulic conductivity functions were estimated, thus enabling a greater understanding of the hydraulic behavior of the materials involved. The non-woven geotextiles and residual soil presented WRC, as expected, similar to the WRC presented in the literature for similar materials.
\end{abstract}

\section{Introduction}

Capillary barrier, a type of evapotranspiration cover (ETC), is a technology that has been successfully used in climates where evapotranspiration overcomes precipitation, Zhang et al. (2016) [1]. It can be used as a final cover for solid wastes, including mining tailings and wastes, with the function of flow control, both in the basal percolation of water and in the control of gas flow from waste decomposition. These barriers are designed with the permeability contrast of its constituents, basically the fine soil overlapping the thick soil. The replacement of the thick soil by a non-woven geotextile (NGT) has improved the performance of the capillary barrier system, Pickles \& Zornberg (2012) [2\}; Zornberg et al. (2016) [3]; De Lima et al. (2017) [4]. Therefore, the study of the capillary barrier requires the understanding of soil and geosynthetics, and the hydraulic characteristics and flow behavior at the soilgeosynthetic interface, McCartney et al. (2008) [5].

Adapted hanging column tests and filter paper tests were carried out on a wetting-drying path in order to obtain the responses of the capillary barrier behavior associated with different NGT soil samples in order to determine their WRC.

\section{Contextualization}

In the process of wetting and drying it is common to have a distinct response to water retention in the soil, a phenomenon known as hysteresis, De Lima et al. (2015) [6]. Hysteresis is mainly attributed to non-uniformity of pore size distribution, known as the "ink bottle effect", the distinct spatial connectivity of the pores according to the path taken and whether the solid-liquid interface advances or recedes, in other words the variation of the liquid-solid contact angle, Hillel (1998) [7]; Marinho et al. (2015) [8].
The WRC assists in the estimation of unsaturated hydraulic conductivity from the known saturated hydraulic conductivity, ASTM D 6836 (2002) [9]. For most practical problems, the approximation of the values of soil properties is adequate for the analysis to be done, which gives importance to empirical methods for estimation of unsaturated soil parameters. The empirical relationship between the saturated soil hydraulic conductivity coefficient and WRC is used in order to predict the hydraulic conductivity of an unsaturated soil, Fredlund \& Xing (1994) [10].

The water retention curve is related to water retention energy (suction) and water content, Barreto et al. (2012) [11], in other words, is the quantifier of water storage in the soil or other porous material, illustrating how water behaves within a porous material and the energy required for water removal. For geotextiles, the WRC reports the storage capacity or variation of the volume of water in its pores influenced by capillary pressure variation, De Lima et al. (2014) [12]. In the prediction of the NGT behavior the determination of the WRC through the wetting path is preferable, since the water entry value for the NGT is lower than the air entry value and therefore, governs the breakdown of the soil-NGT capillary system.

In soil science, the volumetric water content is the most usual parameter to represent the WRC, whereas gravimetric water content is more often used in practical geotechnical engineering. The degree of saturation is also used to represent the WRC. The water content reaches the residual condition when the additional water removal is only possible for large changes in the value of the matric suction. The residual water content is obtained from the ordinate of the point intercepting the tangent extension to the inflection point of the WRC at high suction levels with the straight extension of the residual condition. The value of slightly less than $10^{6} \mathrm{kPa}$ of the total suction for the zero water content was determined by assays for a variety of soils, Croney \& Coleman 
(1961) [13], and verified by thermodynamic considerations, Richards (1965) [14] apud Fredlund \& Xing (1994) [10]. Croney \& Coleman (1961) [13], through experimental data, verified that after reaching the residual water content, the value of water content decreased linearly up to the maximum suction value.

The Capillary Barriers associated with NGT were studied by Pickles \& Zornberg (2012) [2]; Zornberg et al. (2016) [3]; De Lima et al. (2017) [4]. The NGT have larger pores than most soils and their hydraulic conductivity is high when saturated and reduced or nonexistent in almost any unsaturated condition, Stormont et al. (2001) [15]. Capillary barriers with geotextile usually perform better than capillary barriers composed of only soil, Zornberg et al. (2010) [16]; Zornberg et al. (2016) [3].

Heibaum (2010) [17], apud De Lima et al. (2015) [6] defined "capillary layer" as the thin layer of soil which holds the water and "capillary block" as the layer of thick granular material which blocks water. Low plasticity silts and clays are the main soils used as capillary layers, Zornberg et al. (2010) [16]. For the detailing of a capillary barrier, it is important to know the critical suction associated with the capillary rupture and the behavioral change in the hydraulic conductivity versus the water content, between the capillary block and the capillary layer, De Lima et al. (2015) [6]. The critical suction is defined as the suction at which the value of the hydraulic conductivity of the capillary block equals to the hydraulic conductivity of the capillary layer. When this occurs, any decrease in suction confers the rupture of the capillary barrier and the fluid of the fine material is able to flow into the thick material, McCartney et al. (2008) [5]; Zornberg et al. (2010) [16]; De Lima et al. (2017) [4]. In the capillary breaking effect, suction continuity is assumed, even at the interface of two different materials, Zornberg \& McCartney (2007) [18].

Soil suction measurement methods are divided into direct methods which measure matric suction and indirect methods which measure matric, osmotic and total suction and use sensors to measure parameters that can be related to suction through calibration, Agus \& Schanz (2005) [19]. The techniques to determine the water retention curve can be divided into two main groups: physical techniques (low suctions) and thermodynamic techniques (high suctions). The most commonly used tests, due their relative laboratory simplicity, to determine the retention curve, are: hanging column, pressure plate, filter paper and vapor equilibrium, Marinho et al. (2015) [8].

The WRC in the NGT were stated by Stormont et al. (1997) [20] through the adapted hanging column test. They are influenced by the conditions of use of the NGT, that is, whether or not the surface coverings from the manufacturing process have been removed and whether soil particles have gotten into the fibers of the geotextile, Henry \& Holtz (1997) [21]; Stormont \& Morris (2000) [22], apud Stormont et al. (2001) [15]. De Lima et al.
(2014) [12] also used the same methodology to determine WRC for NGT. The methods for determining WRC for geotextiles have not yet been standardized, Pickles \& Zornberg (2012) [2].

The filter paper technique is simple and inexpensive. It can be summarized as the transfer of water from the soil to the paper, until both are in equilibrium. In direct soil-paper contact the capillary flow overcomes capillary forces and the matric suction is measured. The flow of steam overcoming osmotic and capillary forces occurs when there is no soil-paper contact providing total suction, Marinho et al. (2015) [8].

\section{Material and methodology}

The characteristic lithotypes of the source area of the residual soil used in this research were the rocks of the Belo Horizonte complex. The characteristics of a soil are determined by its genesis and the boundary conditions to which it is exposed. So two residual soils of the Belo Horizonte Complex may behave differently depending upon their spatial location. (Paula Neto, 2019) [23]. The area is near where the basement contact (Belo Horizonte complex) meets the Sabará Group, overlapping the Belo Horizonte complex in the region of the confluence of the rivers Córrego dos Britos and Ribeirão Arrudas, where the soils are predominately gneissic residual soils. Removal of the deformed sample was limited to the horizon of the range of 1 to 2 meters deep.Table 1 shows the results of the characterization tests of the residual soil of the border region between the municipalities of Belo Horizonte and Sabará.

Table 1 - Characterization of the residual soil

Natural gravimetric/hygroscopic gravimetric water contents (\%)

$12.7 / 1.0-2.0$

Particle density $\left(\mathrm{g} / \mathrm{cm}^{3}\right)$

2.59

Liquid/Plastic limits/Plasticity index

$(\%)$

$31.8 / 22.0 /$

9.8

Maximum dry density $\left(\mathrm{g} / \mathrm{cm}^{3}\right)$ (standard Proctor compaction effort)

1.8

Optimum water content (\%)

(standard Proctor compaction effort)

Permeability $(\mathrm{cm} / \mathrm{s})$ (saturated) $4.4 \times 10^{-7}$

The particle size distribution analysis of the residual soil was carried out by sieving and sedimentation with a deflocculant (sodium hexametaphosphate $45.7 \mathrm{~g}$ / water 
$1000 \mathrm{~cm}^{3}$ ) and resulted in the particle size distribution of seen in Fig.1. The material was well graded with a slight predominance of the fraction greater than or equal to sand on the fine material, according to the Unified Soil Classification System - USCS -, It is sand with silt and subordinately clay (SM).

Two types of non-woven geotextiles of mass per unit area, composition and different manufacturers were selected, one of wich was GTB, a black polyester geotextil with mass per unit area of $137 \mathrm{~g} / \mathrm{m}^{2}$ and thickness of $1.27 \mathrm{~mm}$ and the other is called GTA, a white polypropylene geotextil with mass per unit area of $259 \mathrm{~g} / \mathrm{m}^{2}$ and thickness $2.07 \mathrm{~mm}$. These values were obtained in the laboratory according to thickness and mass tests per unit area for geotextiles set by ABNT NBR ISO 9863 (2013) [24] and ABNT NBR ISO 9864 (2013) [25].

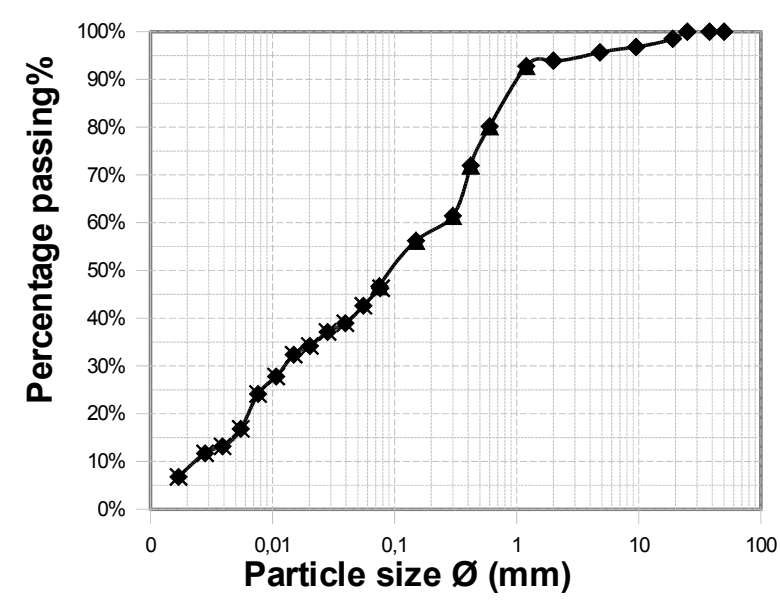

Fig. 1 - Particle size distribution curve of the residual soil "use of deflocculant sodium hexametaphosphate $45.7 \mathrm{~g}\left(\mathrm{NaPO}_{3}\right)_{6}$ $/ 1000 \mathrm{~cm}^{3}\left(\mathrm{H}_{2} \mathrm{O}\right)$ '.

The NGT was new, that is, with the same characteristics as when it left the factory. For the permissivities and apparent opening sizes of the NGT, the characteristic values provided by the manufacturers' were considered, Table 2.

Table 2 - Properties of GTA and GTB according to the manufacturers' characteristic values

\begin{tabular}{ccc}
\hline Hydraulic Properties & GTA & GTB \\
\hline $\begin{array}{c}\text { Apparent Opening Size } \\
(95 \%)(\mathrm{mm}) \text { - ASTM 4751 }\end{array}$ & 0.23 & 0.23 \\
\hline $\begin{array}{c}\text { Water Permeability } \\
(\mathrm{cm} / \mathrm{s}) \text { - ASTM 4491 / } \\
\text { ABNT NBR 15223 }\end{array}$ & 0.23 & 0.44 \\
\hline $\begin{array}{c}\text { Permittivity* } \\
\left(\mathrm{s}^{-1}\right) \text { - ASTM 4491 / } \\
\text { ABNT NBR 15223 }\end{array}$ & 1.11 & 3.46 \\
\hline
\end{tabular}

* Ratio between normal permeability (manufacturer) and thickness determined in LabGeo
In Table 3 the characteristic values of mass per unit area and thicknesses provided by manufacturing companies and those measured in the laboratory. The samplings, in addition to adhering to the national Brazilian standards, were verified according to the Student's t distribution, two-sided $95 \%$ confidence interval.

Table 3 - Mass values per unit area and thickness of GTA and GTB

\begin{tabular}{|c|c|c|c|c|}
\hline & $\begin{array}{c}\text { GTB } \\
\left(\mathrm{g} / \mathbf{m}^{2}\right)\end{array}$ & $\begin{array}{l}\text { GTB } \\
(\mathrm{mm})\end{array}$ & $\begin{array}{c}\text { GTA } \\
\left(\mathbf{g} / \mathbf{m}^{2}\right)\end{array}$ & $\begin{array}{r}\text { GTA } \\
(\mathrm{mm})\end{array}$ \\
\hline Average & 137 & 1,27 & 258,77 & 2,07 \\
\hline $\begin{array}{c}\text { Coefficient } \\
\text { of variation } \\
(\%)\end{array}$ & 10,82 & 11,35 & 4,70 & 4,29 \\
\hline $\begin{array}{l}\text { Standard } \\
\text { deviation }\end{array}$ & 16,56 & 0,32 & 15,22 & 0,09 \\
\hline H0 & $\begin{array}{c}=130 \\
\text { No } \\
\text { reject }\end{array}$ & $\begin{array}{c}=1,1 \\
\text { No } \\
\text { reject }\end{array}$ & $\begin{array}{c}=250^{*} \\
\text { No } \\
\text { reject }\end{array}$ & $\begin{array}{c}=2,1 \\
\text { No } \\
\text { reject }\end{array}$ \\
\hline H1 & $\begin{array}{c}>\text { ou }< \\
130\end{array}$ & $\begin{array}{c}>\text { ou }< \\
1,1\end{array}$ & $\begin{array}{c}>\text { ou }< \\
250\end{array}$ & $\begin{array}{c}>\text { ou }< \\
2,1\end{array}$ \\
\hline $\begin{array}{c}p-\text { value } \\
(5 \%)\end{array}$ & $\pm 2,262$ & $\pm 2,262$ & $\pm 2,179$ & $\pm 2,179$ \\
\hline $\begin{array}{l}\text { Student's t } \\
\text { distribution }\end{array}$ & 1,34 & 2,071 & 2,08 & $-1,07$ \\
\hline
\end{tabular}

Determination of WRC for NGT was accomplished by the ASTM D 6836 (2002) [9] adapted hanging column test. The test apparatus consisted of a Wille Geotechnik panel with a rod-mounted reservoir, which made it possible to vary its height and a $125 \mathrm{ml}$ Büchner Prolab funnel with a porous plate, an upper mouth with a $56 \mathrm{~mm}$ internal diameter and another mouth with an 8 $\mathrm{mm}$ external diameter, coupled to a rod that allowed the height variation of the latter. The funnel rods and the reservoir rods are parallel to each other. Sheets of graph paper comprised the screen of the panel serving as a to gauge of the gap between the funnel and the reservoir, Fig.2. Distilled, ultrafiltered and sterilized water was used in this assay. Both drying and wetting paths were considered. The initial portion of the water retention curve of the residual soil was also defined by this test.

The filter paper test was carried out to determine the water retention curve of the residual soil. This assay was based on ASTM D 5298 (2010) [26] with some adaptations. Twenty-two soil test specimens were made, 11 of which were tested in the wetting path and 11 of which were tested in the drying path. Whatman \# 42 
filter paper was selected and the suction of interest, determined in the test was the matric suction.

The calibration equations of the Whatman \# 42 filter paper chosen in this research were the equations adopted by Chandler et al. (1992) [27].

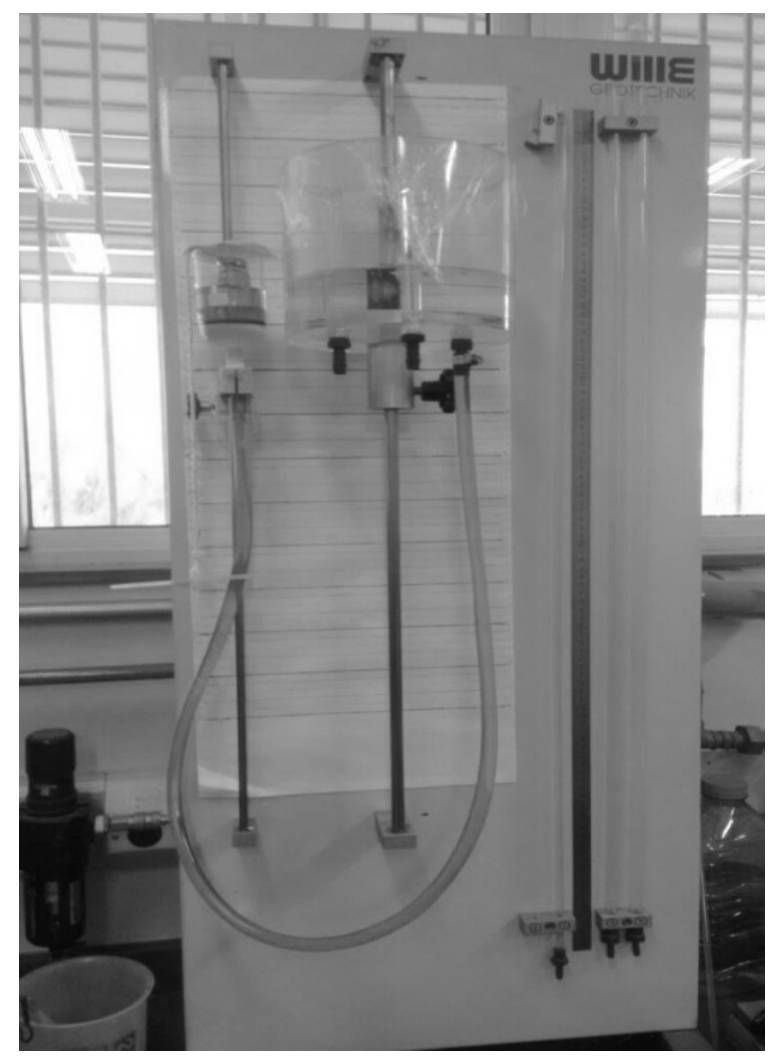

Fig. 2 - Hanging column test.

The WRC were adjusted according to the Fredlund \& Xing (1994) [10] model and the hydraulic conductivity function was provided as proposed by Van Genuchten (1980) [28] and Mualem (1976) [29].

\section{Results}

The water retention curves of GTA and GTB were determined by the adapted hanging column test, as well as the initial portion of the water retention curve of the residual soil. The NGT presented similar responses in the assay and unimodal WRC. The time of suction imposition to the test specimens was approximately 24 hours. The NGT test specimens and the residual soil specimen were always weighed at the end of that time and then saturated and again available to the imposition of the suction of interest, which was generated by the level difference between the funnel and the reservoir. The ambient temperature during the measurements at the time of the measurements ranged between 22 and $25^{\circ} \mathrm{C}$ for GTB, 24 and $26^{\circ} \mathrm{C}$ for GTA and 24 and $26^{\circ} \mathrm{C}$ for the residual soil. At the end of the tests in the drying path, the specimens were placed in a stove at $105^{\circ} \mathrm{C}$ for 48 hours, and then weighed on a $0.01 \mathrm{~g}$ resolution scale.
After the tests, NGT test specimens maintained the same dry weights as before the start of the test, indicating the high porosity of NGT and hydrophobic behavior of the textile fiber. The specimen of the residual soil before the beginning of the test was with its hygroscopic water content, after the test, the soil was placed in the stove and when removed from it had a lower water content than the hygroscopic one. The air entry value of the GTA was close to $0.9 \mathrm{kPa}$ and the air entry value of the GTB was determined to be close to $0.8 \mathrm{kPa}$. The residual water conditions of these NGT presented a water content of $0.05(\mathrm{~S}=5.6 \%)$ at $2.0 \mathrm{kPa}$ for GTA and a water content of $0.03(\mathrm{~S}=3.5 \%)$ a $2.5 \mathrm{kPa}$ for the GTB. In the wetting path, the water entry values $\left(\psi_{\mathrm{ag}}\right)$ for the NGT were $0.05 \mathrm{kPa}$ for the GTA and $0.1 \mathrm{kPa}$ for the GTB. De Lima (2014) [30], in his NGT tests, recorded values of air entry and water entry and residual condition close to those determined for GTA and GTB. In zero suction values, in the same path, the NGT test bodies reached values of water content close to saturation. The calibration parameters of the NGT WRC were obtained graphically according to Fredlund and Xing (1994) [10], Fig. 3.

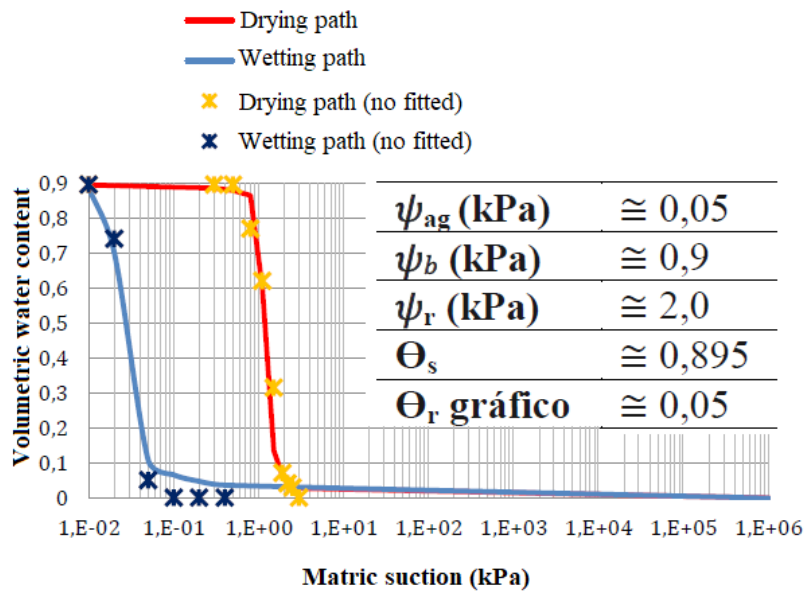

$$
\begin{aligned}
& \text { Drying path } \\
& \text { Wetting path } \\
& \text { * Drying path (no fitted) } \\
& \text { * Wetting path (no fitted) }
\end{aligned}
$$

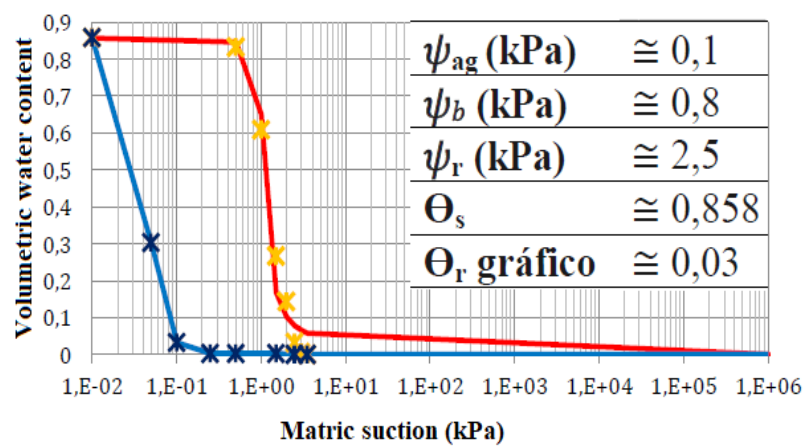

Fig. 3 - NGT WRC fitted. Above - GTA. Below - GTB. 
The determinations of the WRC of the residual soil were made using two different tests, hanging column and filter paper, in the wetting and drying paths. The adjustment parameters of the WRC of the residual soil were obtained graphically as proposed by Fredlund \& Xing (1994) [10], Fig. 4. The adjustment parameters of WRC of the residual soil and values of suction and volumetric water content are listed in Table 4.

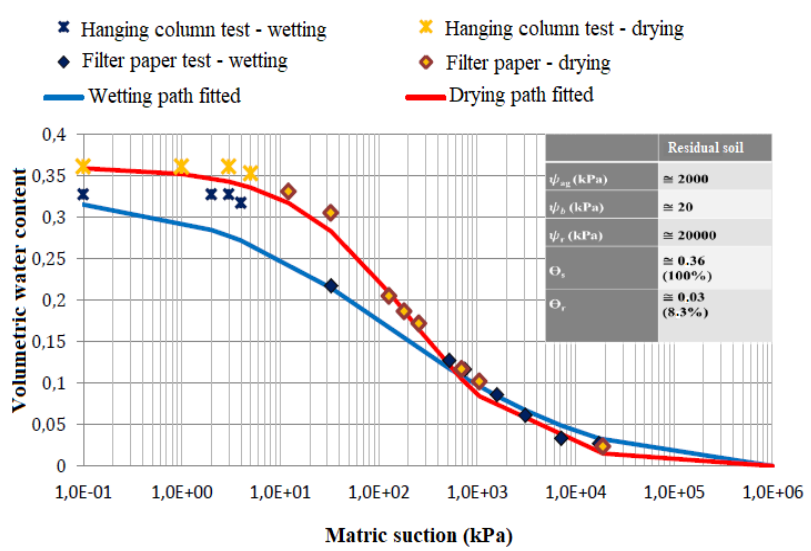

Fig. 4 - Residual soil's WRC.

Table 4 - Parameters and data obtained from the WRC traced by the hanging column test and filter paper test for the residual soil.

\begin{tabular}{cll} 
Parameter & Wetting & Drying \\
\hline$\psi_{\text {ag }}(\mathbf{k P a})$ & $\cong 2000$ & - \\
\hline$\psi_{\mathrm{b}}(\mathbf{k P a})$ & - & $\cong 20$ \\
\hline $\boldsymbol{\psi}_{\mathbf{r}}(\mathbf{k P a})$ & - & $\cong 20000$ \\
\hline $\boldsymbol{\theta}_{\mathbf{s}}$ & $\cong 0.33$ & $\cong 0.36$ \\
\hline
\end{tabular}

In most engineering works, including capillary barriers, wetting paths are the most representative of the critical field situation. Therefore, in addition to the drying paths, the wetting paths were analyzed. Furthermore, the hydraulic conductivity function was estimated according to these paths. The parameters may have variations depending on the chosen path. The critical suctions were determined by the intersection between the conductivity functions of the NGT and the conductivity function of the residual soil by the method of Van Genuchten (1980) [28] and Mualem (1976) [29]. The critical suction and volumetric water contents critical to the breakdown of the capillary barrier with GTA and GTB by drying WRC were respectively 3.0
$\mathrm{kPa}, 0.28(\mathrm{~S}=78 \%)$ and $4.0 \mathrm{kPa}, 0.27(\mathrm{~S}=75 \%)$. The critical suction and volumetric water contents critical to the breakdown of the capillary barrier with GTA and GTB by WRC wetting path were respectively $0.11 \mathrm{kPa}$, $0.31(\mathrm{~S}=86 \%)$ and $0.40 \mathrm{kPa}, 0.30(\mathrm{~S}=83 \%)$. The values of the degree of saturation of the residual soil associated with the breakage of the barrier increased by $0.8 \%$ when comparing the wetting path to the drying path, Fig. 5 and Fig. 6.

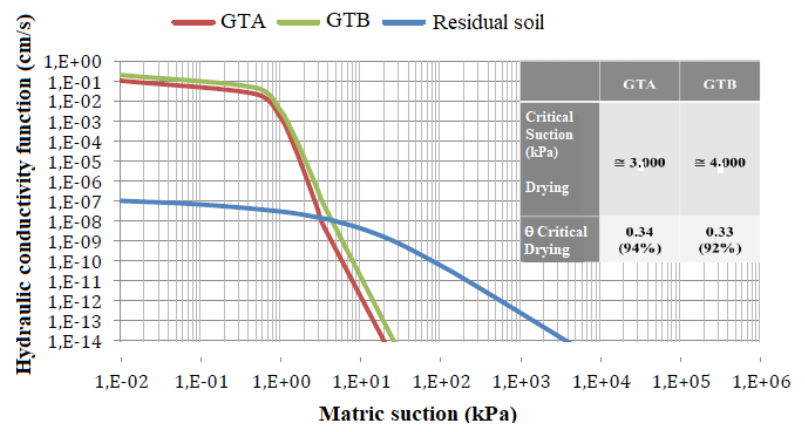

Fig. 5 - Hydraulic conductivity for the residual soil, GTA and GTB. Drying path.

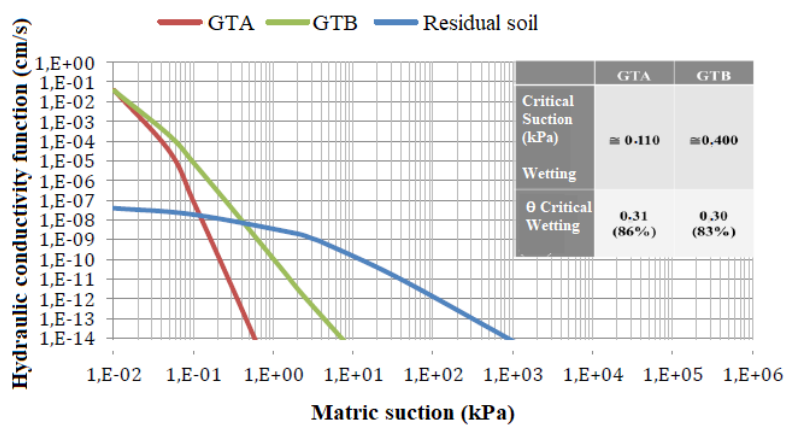

Fig. 6 - Hydraulic conductivity for the residual soil, GTA and GTB. Wetting path.

\section{Discussions}

Some criteria and caveats in the execution of the tests of this research and in the data generated:

- The NGT WRC were obtained by the hanging column test, as it was the most appropriate test for determination of water retention in a medium with high porosity, 0.895 for GTA and 0.858 for GTB.

- Due to the adjustment of the water retention curve in the geotextile to be carried out by the Fredlund \& Xing method, suction $10^{6} \mathrm{kPa}$ for volumetric water content equal to zero was assumed, although the NGT have interconnectable macropores and hydrophobic fibers, it is very probable that for suction well below $10^{6}$ $\mathrm{kPa}$, the NGT were already completely dry, a fact reinforced by the same measured dry weight of the NGT.

- In the wetting path under zero suction conditions, the NGT test specimens reached the same volumetric water content measured when saturated at the beginning of the drying path, despite the hydrophobic fibers that compose them. The capillary rise in the geotextile may 
be due to contributions from the adherence of the test water to the glass of the Büchner funnel and to the arrangement of the fibers of the geotextile.

- Water entry corresponds to the conductivity function presenting lower values than the critical suction. In other words, no water enters the NGT before reaching the critical suction.

- The low critical suctions corresponding to the wetting path indicated the rupture of the capillary barrier in conditions very close to the saturation of the capillary layer, which is reinforced by the graphical proof of the similarity of the unsaturated hydraulic conductivities of the NGT to an approximate value of $1.0 \times 10^{-8} \mathrm{~cm} / \mathrm{s}$ which is very close to the unsaturated hydraulic conductivity of $4.4 \times 10^{-7} \mathrm{~cm} / \mathrm{s}$ for the residual soil.

\section{Conclusions}

The NGT used had similar hydraulic properties, despite having different compositions, and different manufacturing methods, which can cause different performances to the capillary barrier.

The estimation of the unsaturated hydraulic conductivities was made possible by the water retention curves of the residual soil and the non-woven geotextiles. In this article, laboratory tests of hanging column and filter paper, for the determination of WRC and their adjustments, were practical and expedient allowing for support in the design of capillary barriers.

\section{References}

1. W. Zhang, C. Sun, Q. Qiu. (2016). Characterizing of a Capillary Barrier Evapotranspirative Cover Under High Precipitation Conditions. Environ Earth Sci 75: 513. doi:10.1007/s12665-015-5214.

2. C. B. Pickles \& J. G. Zornberg. (2012). Hydraulic Classification of Unsaturated Nonwoven Geotextiles for Use in Capillary Barriers. Second Pan American Geosynthetics Conference \& Exhibition (GeoAmericas 2012). Lima, Perú-13 p.

3. J. G. Zornberg, M. M. Azevedo, C. B. Pickles. (2016). Evaluation of the Development of Capillary Barriers at the Interface Between Fine-Grained Soils and Nonwoven Geotextiles. In: Geosynthetics, forging a path to bona fide engineering materials: in honor of Robert $\mathrm{M}$. Koerner. GSP 275. Y. G. HSUA, S. K. BHATIA, T. Y. SOONG. The American Society of Civil Engineers (ASCE). P341.

4. M. J. De Lima, M. M. Azevedo, J. G. Zornberg, E. M. Palmeira. (2017). Capillary Barriers Incorporating Non-Woven Geotextiles. Env. Geo. ICE - Institution of Civil Engineers, 8p.https://doi.org/10.1680/jenge.16.00038.
5. J. S. McCartney, L. F. S. Villar, J. G. Zornberg. (2008). Nonwoven Geotextiles as Hydraulic Barriers to Capillary Rise. Proceedings of Geoamericas 2008: The 1st Pan American Geosynthetics Conference and Exhibition. Cancún, Mexico. Mar. 2-5. IFAI. pp. 252-261.

6. M. J. De Lima, J. G. Zornberg, E. M. Palmeira. (2015). Barreiras Capilares em Coberturas Evapotranspirativas. In: C. J. Camapum, G. F. N. Gitirana Jr (Org.), S. L, Machado (Org.), M. M. A. Mascarenha (Org.), F. C. Silva Filho (Org.). Solos Não Saturados No Contexto Geotécnico. 1 ed. São Paulo: ABMS, v. 1. 804p.

7. Hillel, D. (1998). Introduction to Environmental soil physics. University of Massachusetts. Amherst, Massachusetts, USA. Academic Press, 1998. 771 p.

8. F. A. M. Marinho, M. A. A. Soto, G. F. N. Gitirana Jr. (2015). Instrumentação de Laboratório e Campo e a Medição da Curva de Retenção. In: C. J. Camapum, G. F. N. Gitirana Jr (Org.), S. L, Machado (Org.), M. M. A. Mascarenha (Org.), F. C. Silva Filho (Org.). Solos Não Saturados No Contexto Geotécnico. 1 ed. São Paulo: ABMS, v. 1. $804 \mathrm{p}$.

9. ASTM D 6836. (2002). Standard Test Methods for Determination of the Soil Water Chararcteristic Curve for Desorption Using a Hanging Column, Pressure Extractor, Chilled Mirror Hygrometer, and/or Centrifuge. American Society For Testing And Materials. 19p.

10. D. G. Fredlund \& A. Xing. (1994). Equations for the Soil-Water Characteristic Curve. Canadian Geotechnical Journal, 31(3): 521-532.

11. H. B. F. Barreto, R. O. Batista, W. O. Santos, F. G. C. Freire, F. G. B. Costa,. (2012). Empirical Models for Estimating Water Retention Curves in Soil in Janaúba-MG, Brazil. Idesia, v. 30, p. 71-76.

12. M. J. De Lima, E. M. Palmeira, J. G. Zornberg. (2014). Determinação de Curva de Retenção de Água de Geotêxtil Não Tecido Utilizando Ensaio de Coluna Suspensa. In: Congresso Brasileiro de Mecânica dos Solos e Engenharia Geotécnica, Goiânia. Anais do COBRAMSEG 7 p.

13. D. Croney, J. D. Coliman. (1961). Pore Pressure and Suction in Soils. Proceeding in Conference om Pore Pressure and Suction in Soild, pp. 31-37, London.

14. B. G. Richards. (1965). Measurement of the Free Energy of Soil Moisture by the Psychrometric Technique Using Thermistors. In: Division of Applied Geomechanics, editor/s. Moisture Equilibria and Moisture Changes in Soils Beneath 
Covered Areas. A symposium in print convened by Soil Mechanics Section, CSIRO, in collaboration with the National Building Research Institute and National Institute for Road Research CSIR, South Africa; Sydney, N.S.W.: Butterworths. 39-46p.

15. J. C. Stormont, C. Ray, T. M. Evans. (2001). Transmissivity of a Nonwoven Polypropylene Geotextile Under Suction. Geotechnical Testing Journal. GTJODJ, Vol. 24, No.2, pp. 164-171.

16. J. G. Zornberg, A. Bouazza, J. S. Mccartney. (2010). Geosynthetic Capillary Barriers: Current State Of Knowledge. Geosynth Int 17(5):273-300

17. M. Heibaum. (2010). Geosynthetics in Agricultural and Aquacultural Applications. In: 9th International Conference on Geosynthetics, Brasil, pp. 259-271.

18. J. G. Zornberg \& J. S. Mccartney. (2007). Chapter 34: Evapotranspirative Cover Systems for Waste Containment. The Handbook of Groundwater Engineering, 2nd edition. Jacques W. Delleur, Editor, CRC Press, Taylor \& Francis Group, Boca Raton, FL.

19. S. S. Agus \& T. Schanz. (2005). Comparison of four Methods for Measuring Total Suction. Vadose Zone J., 4, 1087-1095.

20. J. Stormont, K. Henry, T. Evans. (1997). Water Retention Functions of Four Nonwoven Polypropylene Geotextiles. G.I. 4 (6): 661-672.

21. K. S. Henry \& R. D. Holtz. (1997). Capillary Rise of Water in Geotextiles. Proceedings, International Symposium on Ground Freezing and Frost Action in Soils, S. Knutsson, Ed., Luleå, Sweden, 15-17 April, pp. 227-233. In: J. C. STORMONT, C. RAY, T. M. EVANS. (2001) Transmissivity of a Nonwoven Polypropylene Geotextile Under Suction. Geotechnical Testing Journal, GTJODJ, Vol. 24, No.2, pp. 164-171.

22. J. C. Stormont \& C. E. Morris. (2000). Characterization of Unsaturated Nonwoven Geotextiles. Advances in Unsaturated Geotechnics, IIn: J. C. STORMONT, C. RAY, T. M. EVANS.
(2001) Transmissivity of a Nonwoven Polypropylene Geotextile Under Suction. Geotechnical Testing Journal, GTJODJ, Vol. 24, No.2, pp. 164-171.

23. D. J. Paula Neto. (2019). Influência da Estrutura no Comportamento Hidromecânico de um Solo Tropical Residual de Gnaisse Do Complexo Belo Horizonte - Dissertação (mestrado, xviii,115 f.: il., color.). Universidade Federal de Minas Gerais, Belo Horizonte.

24. ABNT NBR ISO 9863. (2013). Geossintéticos Determinação da Espessura a Pressões Especificadas. Parte 1: Camada Única. Associação Brasileira de Normas Técnicas, São Paulo, SP, 5p.

25. ABNT NBR ISO 9864. (2013) - Geossintéticos Método de Ensaio para Determinação da Massa por Unidade de Área de Geotêxteis e Produtos Correlatos. Associação Brasileira de Normas Técnicas, São Paulo, SP, 2p.

26. ASTM D 5298. (2010). Standard Test Method for Measurement of Soil Potential (Suction) Using Filter Paper. American Society for Testing and Materials. 6p.

27. R. J. Chandler, M. S. Crilley, G. MONTGOMERYSMITH. (1992). A Low-Coast Method of Assessing Clay Desiccation for Low-Rise Buildings. Proc. Instn. Civ. Engrs Civ. Engng. May, 82-89p.

28. M. T. Van Genuchten. (1980). A Closed-Form Equation for Predicting the Hydraulic Conductivity of Unsaturated Soils. Soil Sci. Soc. of Ame. J. 44: 892-898.

29. Y. A. Mualem. (1976) New Model for Predicting The Hydraulic Conductivity of Unsaturated Porous Media. Water Resources Research, Vol. 12 (3). p. 513-522. 1976.

30. M. J. De Lima. (2014). Utilização de Geotêxtil Não Tecido como Elemento Constituinte de Barreiras Capilares. Tese de Doutorado, Publicação GTD 095/14, Departamento de Engenharia Civil e Ambiental, Universidade de Brasilia, Brasília, DF, $128 \mathrm{p}$. 